
Blintsov V.,
Kucenko P.

\title{
GENESIS OF TECHNOLOGIES AND WAYS TO IMPROVE DESIGN AND CONSTRUCTION OF TOWED UNDERWATER SYSTEMS FOR SHALLOW-WATER AREAS
}

Об’єктом дослідження є технологї проектування буксируваних підводних систем для мілководних акваторій. Предметом дослідження є шляхи підвищення продуктивності та зниження витрат на проектування та виробництво буксируваних підводних систем.

При виконанні дослідження було застосовано методологію системного підходу, методи структурного аналізу, математичного моделювання та 3D-проектування, адитивні технології виготовлення конструкцій буксируваних підводних систем.

Виконано системний аналіз закономірностей розвитку технологій проектування буксируваних підводних систем. Сформульовано перспективні напрямки їх подальшого розвитку як необхідну умову підвищення ефективності проектних робіт на основі сучасного інструментарію проектування та забезпечення конкурентоспроможності на ринку морської техніки. Запропоновано доповнити традиційні етапи проектування таких систем трьома новими етапами, які втілюють сучасні тенденцї̈ створення морської техніки. Розроблено генезис технологій проектування буксируваних підводних систем як науково-методологічну основу їх подальшого розвитку у напрямку підвищення ефективності проектних робіт та зниження витрат часових і фінансових ресурсів. Теоретично обгрунтовано доцільність розвитку технологій проектування буксируваних підводних систем шляхом уведення у проектну практику трьох технологій:

- технологї інформаційного моделювання основних усталених та перехідних режимів буксируваних підводних систем на основі системного підходу, доповненого критеріями оцінки витрат на їхнє будівнищтво та експлуатацію;

- ВIM-технологіi (Technologies of the Building Information Modeling) як інформаційної підтримки процесів проєктування, будівництва та подальшої експлуатації створюваної буксируваної підводної системи;

- адитивної технологї виробництва елементів та вузлів буксируваної підводної системи на основі отриманих результатів від попередніх технологій як ефективного шляху скорочення загальних витрат фінансових і часових ресурсів та зниження собівартості створюваних буксируваних підводних систем.

Практична значимість роботи полягає у підтвердженні ефективності та промислової перспективності запропонованих технологій, яке було отримане у результаті їх часткового впровадження у проектну та виробничу практику при створенні буксируваної підводної системи проекту «Глайдер».

ключові слова: буксирувана підводна система, інформаційне моделювання, адитивна технологія виробництва, морська техніка.

Received date: 16.01 .2020

Accepted date: 20.02 .2020

Published date: 30.04 .2020
Copyright (C) 2020, Blintsov V., Kucenko P.

This is an open access article under the CC BY license (http://creativecommons.org/licenses/by/4.0)

\section{Introduction}

Towed underwater systems (TUS) are traditional technical means of studying the aquatic environment and performing a wide range of exploratory, environmental and industrial work [1-3]. Significant volumes of such work are carried out in shallow water areas with depths of up to 100 meters. It is in such water areas that the search and production of marine products is carried out today, work is being done on mapping the bottom surface and the safe operation of coastal waterways, underwater archaeological research, etc. [4-6]. This makes urgent the task of designing and constructing TUS for shallow water areas.

The main application schemes and the typical composition of towed TUS respectively by a towing boat (TB), a towing helicopter (TH) and an autonomous underwater towing unit (AUTU) are shown in Fig. 1.

Typically, TUS is used from the side of a towing boat (TB), on which the surface components of the system are located: TUS power and control station (PCS) and cable winch (CW) [7]. With the help of the cable, the length of the cable tug (CT) part is omitted, depending on the TB depth and speed, and also the CT is saved in the interoperation period (Fig. 1, $a$ ). An unmanned towed underwater unit (TUU) is lowered into the water before towing begins and rises aboard the $\mathrm{TB}$ after completion of work using a round-trip device (RTD).

When performing underwater exploratory work, when the object of the search is explosive objects, or when such work in remote areas is necessary to be carried out promptly, 
the TUS delivery to a given area and its use will be organized from the helicopter [8] (Fig. 1, b).

A promising direction for the TUS use is their installation on small-sized unmanned autonomous underwater units (AUU), which, thanks to towing a TUU with a radio antenna, are able to work under the control of a coastal control post operator in real time [9] (Fig. 1, c).
Another area of work for the further development of TUS design technologies is the involvement of modern scientifically based approaches and methods for performing design work itself and their automation. The main goal here should be to reduce the cost of resources (human, financial, time) for the creation of new TUS models and, as a result, increase their competitiveness in the MRM market.
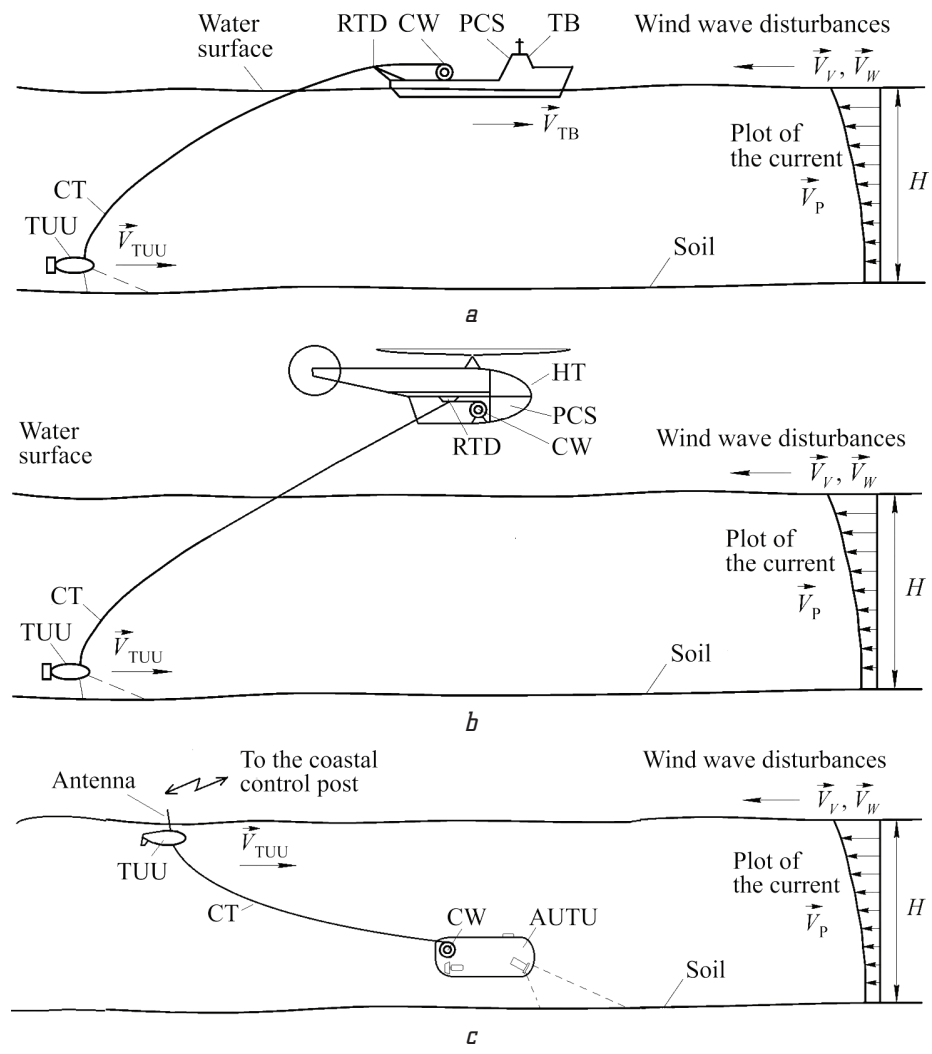

Fig. 1. Typical components of an unmanned towed underwater system: $a$ - towing using a surface ship; $b$ - towing using a helicopter; $c$ - towing using an underwater unit

The above examples of the TUS use indicate that they form a separate type of marine equipment, the creation of which is carried out using modern design and construction methods. This will ensure a reduction in the cost of the created equipment and its high competitiveness in the domestic and foreign markets of crewless underwater systems.

\section{The object of research and its technological audit}

The object of research is the design technology of towed underwater systems for shallow water areas. The subject of research is ways to increase productivity and reduce costs for the design and manufacture of towed underwater systems.

An analysis of the formation of an applied scientific direction in the creation of marine robotics means (MRM) TUS design and construction is a necessary component of the process of its further development. Since it makes it possible to identify and evaluate its laws, as well as outline problematic issues of the current state of the problem and their solution. Currently, the issues of the TUS genesis of design technologies are not covered in the scientific and technical literature.

\section{The aim and objectives of research}

The aim of research is to improve the design methodology for towing underwater systems for shallow water areas by introducing modern technologies for information support of design and production work as the basis for increasing competitiveness in the underwater equipment market.

To achieve this aim it is necessary to solve the following objectives:

1. On the basis of a critical analysis of modern technologies for designing marine engineering facilities, justify the feasibility and possibility of attracting the latest information technologies for design and production work to the TUS design process.

2. To formulate the content of the latest technologies for designing and building TUS, based on modern achievements of science and technology.

3 . To present the results of the practical use of the latest design and construction technologies for TUS and to show their effectiveness for TUS small-scale production.

\section{Research of existing solutions of the problem}

Designing marine equipment refers to complex types of engineering activity, which combines the implementation of a large amount of calculation work and the production of working drawings for their construction [10, 11].

In most cases, such work requires preliminary research and production work $[2,12]$. In modern scientific, technical and industrial literature, the issues of TUS scientific research and are most fully covered. So, in [13], the feasibility of using TUS in shallow water areas was substantiated, however, the authors do not consider the design issues of such a technique.

In [14], the possibilities of using modern computer-aided design (CAD) systems in the shipbuilding industry are considered. In particular, the issues of decoupling applied research and their use in design activities are considered. Comparative analysis of the most used CAD systems has practical value for designers. However, the authors do not make the necessary generalizations for combining research design and manufacturing of drawings for the construction of ships.

The work [15] is devoted to the use of CAD systems (Computer-aided design) for the development of geometric models of structural elements of ships. However, the authors do not consider the use of such systems for the construction of submarine hulls.

In [16], issues of designing an underwater manipulator based on the use of the Robot Operating System CAD platform are considered, however, automation of other elements of underwater vehicles is not considered. 
In $[17,18]$, questions of the practical application of application software packages, respectively, MATLAB ${ }^{\circledR}$ and Simulink ${ }^{\circledR}$ and SolidWorks for computer simulation (using CAD) of underwater robotic vehicles, are studied. However, the authors remain outside the scope of the systematic approach to the design process and its automation.

The work [19] is devoted to geometric modeling of ship surfaces in the environment of the computer-aided design system KOMPAS-3D. The authors consider a method for modeling a ship's hull based on the use of the flat section method, methods for increasing the accuracy of a ship's frame surface, are modeled, etc. However, geometric modeling of hydrodynamic forms of underwater vehicles is not considered.

Thus, the analysis of publications shows that today researchers and designers of marine technology have focused on the automation of typical design work on the design of ships and on computer technologies for performing individual scientific research. Automation of the MRM design, in particular, towed underwater units and systems, is at the initial stage of its development.

Therefore, one of the promising areas for further improvement of design methods for compulsory medical insurance is the development of the genesis (description of the origin, formation and development) of TUS design technologies and the search for ways to increase their effectiveness to ensure competitiveness in the domestic and foreign markets of underwater equipment.

\section{Methods of research}

The following scientific methods are used:

- system analysis method in studying the existing stages of development of TUS design methods and determining the directions for their further development;

- structural analysis method in the formulation of the content of the latest technologies for the TUS design and construction;

- information modeling method when creating 3D models and information models of a towed underwater unit as a TUS component;

- method of information modeling of construction objects (BIM-technology) for information support of the design, construction and subsequent operation of the created TUS;

- methodology for a systematic approach using the equations of existence of TUS components at the early stages of TUS design;

- additive technology methodology for organizing smallscale production of TUS elements and units.

\section{Research results}

6.1. Genesis of TUS design technologies. Analysis of the design methods for the TUS indicates that their development took place at the following enlarged stages, typical of the shipbuilding industry as a whole:

- manual design (MD), when the drawings of the TUS elements and units were carried out by the designers manually on the curtains, and the project product documentation was the paper documentation;

- two-dimensional (2D) design as the initial stage of automation of manual labor of designers, the result of which was project documentation in electronic formats «.pdf», «.dwf», «.dwg» created using Autodesk, AutoCAD and other software products. This stage is characterized by the implementation of the principles of CAD design (in English literature - Computer Aided Designes) and, at the same time, the lack of full-fledged information links between TUS designers [20];

- three-dimensional (3D) design, which is based on the principles of geometric modeling and management of digital ordered design information generated by $2 \mathrm{D} / 3 \mathrm{D}$ CAD systems and stored in a common data environment (in the English language literature - Common Desktop Environment, CDE) [19]. The result of three-dimensional design is a set of structured containers (data sets) about the designed TUS, which form the information basis for the generation of working design documentation for its construction;

- computer support systems for engineering calculations (in English literature - Computer-Aided Engineering, SAE), designed to solve engineering problems, for example, for calculating structural strength, assessing the forces of hydrodynamic nature, calculations of elements, units and systems of TUS [21].

Today, in the shipbuilding industry, the stages of development of design methods are indicated; they have formed into a number of specialized computer-aided design systems (CAD), which are widely used in the design practice of leading companies. The most famous CAD systems include FORAN (Spain), TRIBON (Sweden), NUPAS-CADMATIC (Holland and Finland), CATIA (USA) and others [22].

However, in the practice of designing TUSs, CAD systems are not actually used because of their specifics associated with the design of ships and yachts.

An analysis of the development of other industries (construction, aviation, etc.), as well as the experience of the authors in the design, construction and operation of compulsory medical insurance, allows to supplement the above four stages of the TUS design with three additional steps. The proposed stages have already been implemented in the practical activities of the scientific research institute of underwater technology of the Admiral Makarov National University of Shipbuilding (Mykolaiv, Ukraine), or are planned for implementation in the near future:

- information modeling stage (in English literature Information Modeling, IM) of TUS, which covers the processes of creating and using coordinated structured information models. These models describe the technical and operational characteristics of the design object and object-oriented three-dimensional geometric characteristics of its components created by various participants during the life cycle of the design object within the CDE framework. A distinctive feature of the MI stage is the widespread use of computer modeling methods (in the English literature - Computer Simulations, CS) for studying the operating modes of the future TUS in established and dynamic modes. And also for using the obtained data in design decisions - from the development of specialized modeling systems (SMS) [23, 24] and to the use of computational fluid dynamics programs (in the English literature - Computational Fluid Dynamics, CFD [25]). The result of information modeling is new knowledge about the properties of the created TUS, which allow to clarify the operational characteristics of the TUS already at the early stages of its design; - stage of BIM technologies (in English literature Building Information Modeling, BIM), which provide 
for the use of a general digital representation of the object is created to provide information support for the design, construction and operation processes. The purpose of creating a reliable basis for decision making [26]. Today, such technologies implement the latest approaches to building design; their application in the creation of TUS should include the collection and integrated processing of design (CD), technological (TD) and economic (ED) information about TUS in the process of its design. The result of this stage should be a common $C D E_{V I M}$ data environment, which will allow to evaluate both the technical and economic characteristics of the new underwater equipment being created in the early stages of design;

- stage of providing additive production technologies (in English literature - Additive Production Technologies, APT), which provides for the integration of design work with the manufacture of designed parts, elements and units of TUS by $3 \mathrm{D}$ printing. Behind them, products are manufactured according to the data of a three-dimensional digital model (3D design stage) by the method of layer-by-layer addition of structural materials [27]. The result of this stage is the production of non-serial elements and parts of TUS structures using 3D printing technologies, which have a significantly lower cost compared to traditional small-scale production technologies.

The genesis (origin, formation, development) of TUS design technologies (in English literature - Technologies of Design, TD) is shown in Fig. 2.

In Fig. 2 subscripts correspond to the above stages of development of design methods.

Let's consider the content of the last three stages in more detail.

6.2. TUS information modeling stage. The stage of information modeling significantly affects the further efficiency of the future TUS, since it is here that at its early stages of design its main design parameters and operational characteristics are determined.

Usually, at this stage, applied scientific research is carried out to preliminary assess the TUS properties in the main operating modes (quasistationary and transient modes), a preliminary check of the TUU hydrodynamic characteristics is performed, and the like.
Based on the practice of the authors in the design of TUS, it is possible to formulate the following priority tasks for creating $T D_{I M}$ : information modeling technology: - development of 3D-models of $I M_{3 \mathrm{D}}$ TUS components (in the first place - the development of the TUS design as the most complex design object). It is advisable to use application packages of two- and three-dimensional interactive computer-aided design systems as CAD tools here (CAD-packages of AutoCAD and/or COMPAS-3D programs $[19,28])$;

- creation of informational (mathematical) models of $I M_{T U S}$ TUS components (first of all, TUU, CT) as solid and flexible bodies in a water stream that have force interaction between themselves - for a computer study of established and dynamic TUS operation modes. It is advisable to use the software package for solving Matlab engineering calculations problems [29] or create specialized modeling complexes for mass multivariate calculations [23, 24]; - creation of information (mathematical) models of $I M_{C A C S}$ for automatic control system of TUS components in the main operating and emergency modes to check the TUS controllability and the quality of the underwater work [30]. It is also advisable to use Matlab software packages and/or specialized modeling complexes as tools here;

- development of TUS 3D-models of $I M_{C F D}$ for the study of their hydrodynamic characteristics. It is advisable to use the FlowVision CFD software package as a tool here, which is designed to solve three-dimensional stationary and non-stationary equations of fluid and gas dynamics [31].

Thus, the main tasks of creating information modeling technology $T D_{I M}$ can be represented by the following set of $I M$ mathematical models:

$$
I M=\left\{I M_{3 \mathrm{D}} ; I M_{T U S} ; I M_{A C S} ; I M_{C F D}\right\}
$$

The practical implementation of the information modeling phase in the early stages of design significantly affects the productivity and quality of further design work. It also opens up wide opportunities for reducing the cost of resources for the design and manufacture of both TUS elements and its construction.

The generalized structure of TUS as an object of information modeling at the early stages of design is shown in Fig. 3.

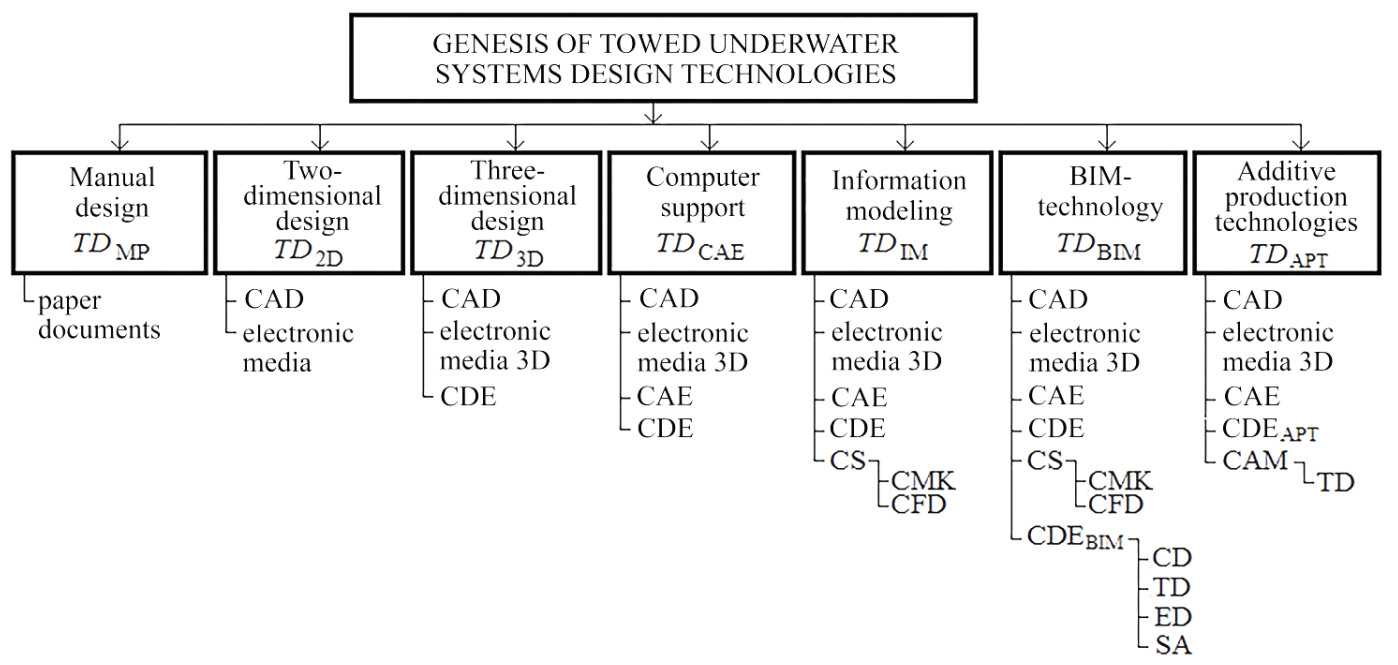

Fig. 2. Genesis of towed underwater systems design technologies 


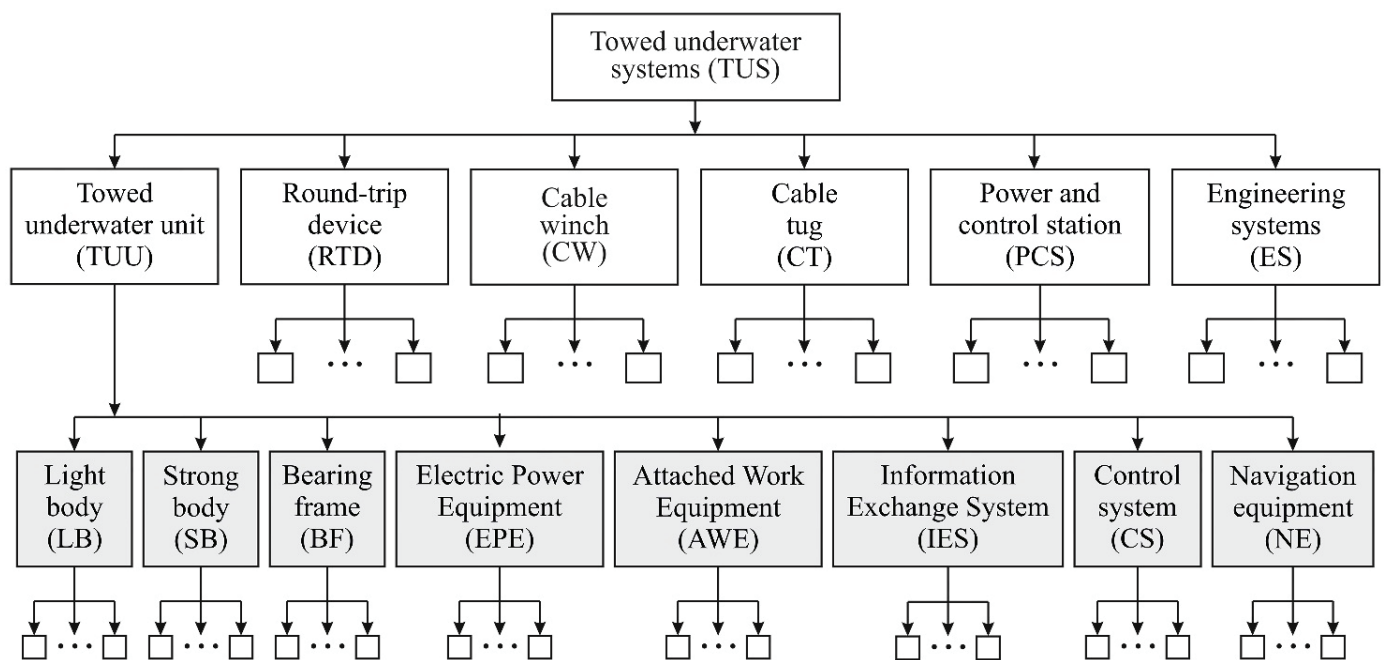

Fig. 3. The generalized structure of the towed underwater system as an object of information modeling in the early stages of design

In Fig. 3 in addition to the typical TUS components shown in Fig. 1, the «Engineering Systems» component is introduced, which contains a transport trolley for moving the TUU along the TB deck, an arrangement for technical maintenance of the TUS in operating conditions, and the like. Taking this component into account makes the list of TUS design work more complete.

Let's consider the implementation features of $T D_{I M}$ information modeling technology using the example of TUU information modeling as the most high-tech component of the system being created.

In Fig. 3 dimming highlighted TUU as the TUS part and its main elements:

- structural elements - light body (LB), which functions are performed by the TUU hydrodynamic fairing; strong electrical equipment bodies (SB); bearing frame $(\mathrm{BF})$ as a TUU power unit;

- TUU energy elements - electric power equipment (power supply system, electric steering wheels, underwater lights, etc.); attached working equipment (search video and hydroacoustic devices, water samplers, sensors of hydrophysical and hydrochemical devices, etc.);

- information elements - information exchange systems for the fuel and energy sector and manual or automatic control of the movement of TUU and attached working equipment; navigation equipment (sensors of TUU spatial position, linear and angular speeds and accelerations).

Using the TUU as an example, let's consider the features of creating a $T D_{I M-T U U}$ information modeling technology.

The development of 3D-models of TUU IM $3 \mathrm{D}-T U U$ already in the early stages of design should ensure a reduc- tion in the timing of design work and a decrease in the total cost of design, to avoid duplication of a significant amount of work performed in the following stages. To do this, the development of the 3D model of the TUU, starting with the preliminary design, is carried out using the same software tool (CAD-packages of AutoCAD and KOMPAS-3D programs) as at the stages of the technical and working design and the manufacturing stage. This ensures that both the $3 \mathrm{D}$ model of the TUU and the $2 \mathrm{D}$ models of the TUU are necessary for the manufacture of working drawings.

In Fig. 4, $a$, a 3D model of the TUU light body of the Glider project manufactured by the Admiral Makarov National University of Shipbuilding is shown. It allows to generate a $2 \mathrm{D}$-drawing of the design object for further use in production (Fig. 4, $b$ ). The TUU of the Glider project corresponds to the towing scheme depicted in Fig. 1, $a$.

TUU design practice of the Glider project indicates that the introduction of 3D design technologies at the early stages of their development reduces the time spent by designers within 25-30\% compared to traditional 2D design technology.

The creation of TUU information models $I M_{T U S-T U U}$ as a TUS component aims, first of all, to study its properties in quasi-stationary (settled) and dynamic (transient) modes. As a rule, such models are created on the basis of systems of nonlinear differential-algebraic equations and are used as part of specialized modeling complexes, which also contain mathematical models of CT, RTD, CW and models of external disturbances (wind-wave, current, TB pitching).

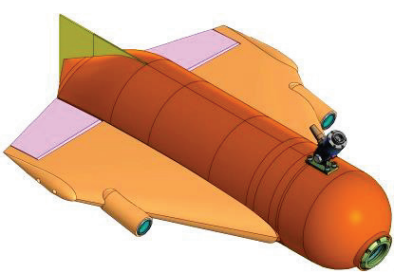

$a$
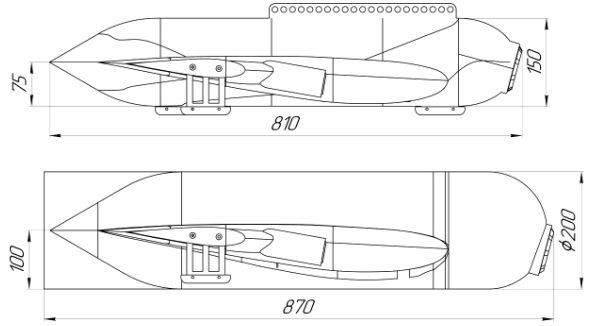

$b$

Fig. 4. 3D model of the light body of the towed underwater unit of the Glider project: $a-3 D$ model of the light body (CAD-package of the KOMPAS-3D program); $b-2 D$ drawings based on the 3D model 
Currently, the theory of mathematical modeling of marine moving objects in general and the TUU, in particular, has been developed quite fully. In many practical cases, when creating a TUU, its mathematical description is used as a solid in the oncoming fluid [32]:

$$
\left.\begin{array}{l}
\frac{d_{A} \vec{P}}{d t}+\vec{\omega} \cdot \vec{P}=\vec{F} ; \\
\frac{d_{A} \vec{L}}{d t}+\vec{\omega} \cdot \vec{L}+\vec{v} \cdot \vec{P}=\vec{M},
\end{array}\right\}
$$

where $\vec{P}$ - momentum of the solid; $\vec{F}$ - main vector of external forces; $\vec{L}$-angular momentum of a solid body of its pole; $\vec{M}$ - main moment of external forces relative to the pole of a solid body, the index $A$ of the differential sign means that the derivative of the vector is calculated relative to the basis $A$, that is, the basis of the coordinate system associated with the TUU body.

Hydrodynamic (viscous) forces and moments appear on the TUU body as a result of interaction with the surrounding aqueous medium during its movement. The determination of these forces is a complex task of hydromechanics, for the solution of which the methods and means of computational hydrodynamics are used and, if necessary, the methods of basin and sea field tests [31, 33]

But when simulating the TUU, they use a simplified representation of these forces and moments by representing them as the sum of a linear and quadratic dependence on the TUU velocity in relation to the aqueous medium [34]:

$$
T_{h}=\left[\vec{F}_{h} \vec{M}_{h}\right]^{T}=D(V) V,
$$

where $\vec{F}_{h}$ - vector of hydrodynamic resistance forces; $\vec{M}_{h}-$ hydrodynamic moment of resistance; $D$ - matrix of resistance parameters; $V$ - TUU velocity matrix (translational and rotating) in relation to water.

The hydrodynamic coefficients, which contain the matrix $D$, are considered constant. For a body completely immersed in water, the following assumption is accepted:

$$
\begin{aligned}
& D(V)= \\
& =-\left(\begin{array}{l}
\operatorname{diag}\left\{a_{l}, b_{l}, c_{l}, p_{l}, q_{l}, r_{l}\right\}+ \\
+\operatorname{diag}\left\{a_{q}\left|v_{x}\right|, b_{q}\left|v_{y}\right|, c_{q}\left|v_{z}\right|, p_{q}\left|\omega_{x}\right|, q_{q}\left|\omega_{y}\right|, r_{q}\left|\omega_{z}\right|\right\}
\end{array}\right),
\end{aligned}
$$

where $a_{l, q}, b_{l, q}, c_{l, q}, p_{l, q}, q_{l, q}, r_{l, q}$ - the parameters of the TUU hydrodynamic resistance; $v_{x, y, z}$ and $\omega_{x, y, z}$ - the projections, respectively, of the translational and rotating velocity vectors of the TUU on the axis of the coordinate system associated with the TUU body.

The experience of using TUS simplified mathematical models in studies of quasistationary and transient TUS modes indicates that with their help, even at the early stages of design, it is possible to obtain substantially new data on the properties of the again system. In particular, during the TUS design of the glider project, the influence of the cable tug on the TUS operation was investigated and highly efficient automatic control systems of the TUU were synthesized [35].

Creation of informational (mathematical) models IM $M_{A C S-T U U}$ of TUU automatic control system (ACS) is an important component of design work in the early stages of their creation. This is due to the fact that, in combination with the information models of the towed underwater unit $M M_{T U S-T U U}$ and cable-tug $M M_{T U S-C T}$, it can significantly reduce the time spent on the development of effective controllers for the TUU spatial movement and ensure the necessary quality of their functioning.

An additional advantage of information modeling of the TUU-CT system, which have force interaction in the water flow, is the rejection of labor-intensive and cost-based marine full-scale tests of TUS and their replacement by computer research technologies, including emergency modes [36]

One of the practical results confirming the effectiveness of using ACS information models is the synthesis of a two-dimensional system for automatic control of the TUS rotational motion at shallow depths under uncertainty [30].

Development of TUS 3D models IM CFD-TUS for the study of their hydrodynamic characteristics relates to the problems of computational fluid dynamics and provides for the numerical solution of differential equations of a viscous fluid (Navier-Stokes equations) using the finite difference or finite volume method. The prospects of this approach are due to the use of the most general and rigorous formulations in the study of the problems of fluid flow around solids [37].

The main difference between FlowVision CFD applications from their analogues is the automatic generation of the computational grid. They implemented automatic generation of the computational grid using an adaptive locally ground grid. Thanks to this technology, the user defines only the general configuration of the rectangular initial mesh, and the construction of cells of complex shape near surfaces with boundary conditions is performed automatically.

The indicated technology requires significant computational resources; therefore, its application for the TUU design tasks is in the initial phase.

In general, the technology of TUU information modeling $T D_{I M-T U U}$ according to (1) will consist of the following groups of information models:

$$
I M_{T U U}=\left\{I M_{3 \mathrm{D}-T U U} ; I M_{T U S-T U A} ; I M_{A C S \_T U U} ; I M_{C F D-T U U}\right\} .
$$

Thus, the use of TUU information modeling $T D_{I M-T U U}$ in the early stages of design allows to gain new knowledge about the design object and its operational properties, as well as search for effective design solutions.

6.3. Stage of BIM-technology in the TUS design. The essence of BIM technology in the TUS design is to provide information support for the design, construction and subsequent operation of the created TUS. In this work, let's consider possible directions for improving the design and construction processes of TUS by involving the following modern methods and technologies.

Application of a systematic approach. It is proposed to design TUS at early stages (technical proposal, conceptual design) based on a systematic approach (in the English literature - System Approach, SA) using the equations of existence of TUS components according to known structural $A$, energy $P$, information $I$ and operational $J$ criteria [38]. According to this approach, for each TUS component (TUU, CT, CW, RTD, PCS), the following two sets of matrices are introduced, each of which contains the technical characteristics of the TUS according to the specified criteria:

1) set of matrices of technical requirements (TR) restrictions on the structural, energy, information and operational characteristics of the components of the created TUS:

$$
E T_{T U S}=\left\{E T_{T U U} ; E T_{C T} ; E T_{C W} ; E T_{R T D} ; E T_{P C S}\right\} ;
$$


2) set of matrices of structural, energy, information and operational characteristics of the TUS components obtained at the current design stage:

$$
E E_{T U S}=\left\{E E_{T U U} ; E E_{C T} ; E E_{C W} ; E E_{R T D} ; E E_{P C S}\right\}
$$

Each component of the set of ET matrices is a column matrix of the TR requirements or more detailed requirements formulated on the TR basis for the structural, energy, information and operational characteristics of the corresponding TUS components:

$$
\begin{aligned}
& E T_{T U U}=\left|\begin{array}{c}
A_{T U U} \\
P_{T U U} \\
I_{T U U} \\
J_{T U U}
\end{array}\right| ; \quad E T_{C T}=\left|\begin{array}{c}
A_{C T} \\
P_{C T} \\
I_{C T} \\
J_{C T}
\end{array}\right| ; \quad E T_{C W}=\left|\begin{array}{c}
A_{C W} \\
P_{C W} \\
I_{C W} \\
J_{C W}
\end{array}\right| ; \\
& E T_{R T D}=\left|\begin{array}{c}
A_{R T D} \\
P_{R T D} \\
I_{R T D} \\
J_{R T D}
\end{array}\right| ; \quad E T_{P C S}=\left|\begin{array}{c}
A_{P C S} \\
P_{P C S} \\
I_{P C S} \\
J_{P C S}
\end{array}\right| .
\end{aligned}
$$

Each component of the set of $E E_{T U S}$ matrices is a column matrix, respectively, of the structural, energy, information and operational characteristics of the corresponding TUS components obtained at the $i$-th current iteration of design calculations:

$$
\begin{aligned}
& E E_{T U U i}=\left|\begin{array}{c}
A_{T U U i} \\
P_{T U U i} \\
I_{T U U i} \\
J_{T U U i}
\end{array}\right| ; \quad E E_{C T i}=\left|\begin{array}{c}
A_{C T i} \\
P_{C T i} \\
I_{C T i} \\
J_{C T i}
\end{array}\right| ; \quad E E_{C W i}=\left|\begin{array}{c}
A_{C W i} \\
P_{C W i} \\
I_{C W i} \\
J_{C W i}
\end{array}\right| ; \\
& E E_{R T D i}=\left|\begin{array}{c}
A_{R T D i} \\
P_{R T D i} \\
I_{R T D i} \\
J_{R T D i}
\end{array}\right| ; \quad E E_{P C S i}=\left|\begin{array}{c}
A_{P C S i} \\
P_{P C S i} \\
I_{P C S i} \\
J_{P C S i}
\end{array}\right| .
\end{aligned}
$$

Let's note that each element of the matrix columns (6) is the sum of, respectively, structural $A$, energy $P$, information and functional $J$ characteristics of one or another component of the created TUS.

A pairwise comparison of the corresponding elements of the matrix columns (5) and (6) after each iteration of the design calculations enables the designer to determine at the early stages of the design the level of compliance of the current technical solutions for the TUS components with the requirements of the technical specifications according to criteria $A, P, I$ and $J$.

Based on the nature of BIM technologies [26], it is proposed to introduce two groups of criteria for the wellknown matrix equations (5), (6) for preliminary estimation of resource costs, respectively, for the building (criterion $B$ ) and operation (criterion $O$ ) of the TUS.

Introduction to the design practice of these criteria allows to evaluate its cost of creation as an object of small-scale production, and competitiveness in the market of marine robotics, as well as to evaluate the cost of operating the TUS at an early stage in the TUS.

Then the matrix relations (5), (6) will be supplemented by the above criteria and will have the form:

$$
\begin{aligned}
& E T_{T U U}=\left|\begin{array}{c}
A_{T U U} \\
P_{T U U} \\
I_{T U U} \\
J_{T U U} \\
B_{T U U} \\
O_{T U U}
\end{array}\right| ; \quad E T_{C T}=\left|\begin{array}{c}
A_{C T} \\
P_{C T} \\
I_{C T} \\
J_{C T} \\
B_{C T} \\
O_{C T}
\end{array}\right| ; \quad E T_{C W}=\left|\begin{array}{c}
A_{C W} \\
P_{C W} \\
I_{C W} \\
J_{C W} \\
B_{C W} \\
O_{C W}
\end{array}\right| ; \\
& E T_{R T D}=\left|\begin{array}{c}
A_{R T D} \\
P_{R T D} \\
I_{R T D} \\
J_{R T D} \\
B_{R T D} \\
O_{R T D}
\end{array}\right| ; \quad E T_{P C S}=\left|\begin{array}{c}
A_{P C S} \\
P_{P C S} \\
I_{P C S} \\
J_{P C S} \\
B_{P C S} \\
O_{P C S}
\end{array}\right| . \\
& E E_{\text {TUUi }}=\left|\begin{array}{c}
A_{T U U i} \\
P_{T U U i} \\
I_{\text {TUUi }} \\
J_{\text {TUUi }} \\
B_{\text {TUUi }} \\
O_{\text {TUUi }}
\end{array}\right| ; \quad E E_{C T i}=\left|\begin{array}{c}
A_{C T i} \\
P_{C T i} \\
I_{C T i} \\
J_{C T i} \\
B_{C T i} \\
O_{C T i}
\end{array}\right| ; \quad E E_{C W i}=\left|\begin{array}{c}
A_{C W i} \\
P_{C W i} \\
I_{C W i} \\
J_{C W i} \\
B_{C W i} \\
O_{C W i}
\end{array}\right| ; \\
& E E_{R T D i}=\left|\begin{array}{c}
A_{R T D i} \\
P_{R T D i} \\
I_{R T D i} \\
J_{R T D i} \\
B_{R T D i} \\
O_{R T D i}
\end{array}\right| ; \quad E E_{P C S i}=\left|\begin{array}{c}
A_{P C S i} \\
P_{P C S i} \\
I_{P C S i} \\
J_{P C S i} \\
B_{P C S i} \\
O_{P C S i}
\end{array}\right| .
\end{aligned}
$$

For example, the cost of construction of the $i$-th TUU version $B_{\text {TUUi }}$ can be estimated as the sum of the costs of resources for the design of $B_{T U U-3 \mathrm{D}}$, information modeling $B_{T U U-I M i}$ and the TUU production $B_{T U U-A P T i}$. Operating costs during the life cycle of the $i$-th TUU version can be aggregated can be estimated by the sum of the costs of the TUU maintenance of the $O_{T U U-M i}$ and capital repairs $O_{T U U-C R i}$. The development of the substantive part of equations (7), (8) is a separate engineering task and is not considered here.

Let's note that dependencies (7), (8) form a complete set of estimates of the ability to create (design, build, and operate) of TUS in accordance with the TR requirements.

6.4. Stage of providing additive technology for the TUS production. Additive technologies for the production of TUS elements and assemblies can significantly reduce the cost of resources (time, finance, etc.) for the creation of both existing models and prototypes and serial models of TUS. In fact, with the advent of $3 \mathrm{D}$ printers, a rapid transition from the classical CAM technology (in the English literature Computer-Aided Manufacture, CAM) to control numerically controlled machines in non-waste technology of additive manufacturing of TUU parts is ensured.

The practical experience of using additive technologies in the production of TUS indicates that the priority objects for such technology include light bodies (LB) and TUU bearing frames $(\mathrm{BF})$, as well as strong bodies (SB) for the TUU electrical equipment (Fig. 3). Thus, the authors' experience in manufacturing a light body (hydrodynamic fairing) and a base frame of a TUU of the Glider project on $3 \mathrm{D}$ printers allows to state the following:

- 3D printer is an ideal tool for the direct use of

$3 \mathrm{D}$ models of TUU in the production of parts; 
- the obtained parts can be used both directly in the TUU design, and as models (geometric models) of these parts for their further surface hardening (for example, using fiberglass).

Fig. 5 shows the results of manufacturing on a 3D printer the elements of a light body (hydrodynamic fairing) of a glider control unit and its bearing surfaces, 3D models of which were developed using the CAD package of the KOMPAS-3D program.

The experience of using additive manufacturing technologies for these TUU elements of the Glider project has shown that the time required for their manufacture has decreased by 15-20 times in comparison with the traditional technology of manual manufacturing of matrices and their gluing with fiberglass. At the same time, the cost of production performed decreased by $12-15$ times.
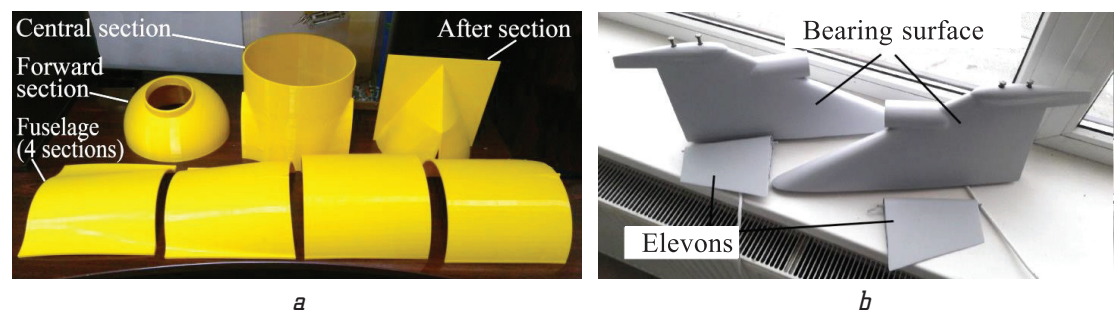

Fig. 5. Elements made using a 3D printer:

$a$ - light body of bearing surfaces; $b$ - TUU elevons of the Glider project zations is the requirement to create a single information space for all participants in the development, construction and operation of the TUS. An additional complication is the need for technical re-equipment of TUS production due to the need to introduce additive technologies as the final stage of the TUS creation process.

Opportunities. The main conditions for the successful and full-scale implementation of the proposed stages of the design, construction and operation of the TUS should include the involvement of organizations developing computer-aided design systems for marine equipment. The result of such cooperation should be a CAD software package that will provide the maximum «digitalization» of the design, construction and operation of TUS processes.

Threats. The main threat to the implementation of the proposed technologies for the design and construction of TUSs may be high initial costs for the development of a single information space for all participants in the process of their development, construction and operation. In addition, additional complexity can be caused by the organization of the additive production of TUS elements, since they are made of various structural materials.
The obtained results indicate that additive technologies make it possible to produce a wide range of TUS structural elements, starting from small parts of the structures of its components (Fig. 3) and ending with the strong bodies (SB) of the TUU and the frame structures of the TUS engineering systems (ES).

\section{SWOT analysis of research results}

Strengths. As a result of the research, directions for improving the design and construction technologies of towed underwater systems for shallow water areas were identified, since it is in these water areas that active economic and scientific activities are being carried out.

The performed review of the stages of development and application of TUS design and construction technologies made it possible to supplement their list in three stages that embody modern trends in the creation of new equipment:

- information modeling technologies for the main established and transitional TUS regimes based on a systematic approach, supplemented by criteria for assessing the costs of their construction and operation;

- BIM technology as a technology of information support for the design, construction and subsequent operation of the towed underwater system;

- additive technologies for the production of TUS elements and nodes based on the results of the previous stages as a main way to reduce the total cost of financial and time resources and reduce the cost of the created TUS.

The proposed technologies provide a modern level of information support for design and production work, and their practical use forms the prerequisites for increasing the TUS competitiveness in the underwater equipment market.

Weaknesses. A difficult aspect of introducing the proposed stages into the practical activities of design organi-

\section{Conclusions}

1. Systematic analysis of the laws of development of TUS design technologies is performed and promising directions for their improvement on the basis of modern design tools and ensuring competitiveness in the marine equipment market are formulated. At the same time, the genesis of design technologies for towed underwater systems is developed as a scientific and methodological basis for their further development and attraction of the latest technologies for information support of design and production work

2. The feasibility of introducing into the design practice the technology of information modeling of the basic TUS modes on the basis of the system approach, BIM technology as information support and additive technology for the production of non-serial TUS elements is theoretically substantiated. The substantial part of these technologies has been developed, the involvement of which in project practice reduces the total cost of financial and time resources and helps to increase the competitiveness of the created TUS.

3. The efficiency and industrial prospects of the proposed technologies for creating TUSs have been practically proved by their partial implementation in design and production practice when creating the TUS of the Glider project. So, the use of 3D design technology in the project has reduced the time spent by designers within 25-30\% compared to traditional 2D design technology.

The use of additive technologies for the production of light TUU cases reduces the time required for its manufacture by $15-20$ times in comparison with the traditional technology for the manual manufacturing of matrices and their gluing with fiberglass. At the same time, the cost of performed production is decreased by $12-15$ times. 


\section{References}

1. Moore, S. W., Bohm, H., Jensen, V. (2010). Underwater Robotics: Science, Design \& Fabrication. Marine Advanced Technology Education (MATE) Center, 770

2. Ryzhkov, S. S., Blintsov, V. S., Yehorov, H. V., Zhukov, Yu. D., Kvasnytskyi, V. F., Koshkin, K. V. et. al. (2011). Stvorennia universalnykh transportnykh suden $i$ zasobiv okeanotekhniky. Mykolaiv: Natsionalnyi universytet korablebuduvannia imen admirala Makarova, 340

3. Towed Vehicles. The Woods Hole Oceanographic Institution. Available at: https://www.whoi.edu/what-we-do/explore/underwatervehicles/towed-vehicles/

4. Zraev, R. A. (2016). Tekhnika pokoreniia morskikh glubin. Neobitaemye podvodnye apparaty vchera, segodnia i zavtra. Molodoi uchenii, 26 (130), 37-39.

5. Iievlev, M. M., Chubenko, O. V., Blintsov, V. S., Nadtochyi, A. V. (2019). Pidvodna arkheolohiia pivnichnoho Prychornomoria: Stan ta perspektyoy rozoytku. Mykolaiv: Natsionalnyi universytet korablebuduvannia imeni admirala Makarova, 336.

6. Jaulin, L., Caiti, A., Carreras, M., Creuze, V., Plumet, F., Zerr, B. Billon-Coat, A. (2017). Marine Robotics and Applications. Springer, 178. doi: http://doi.org/10.1007/978-3-319-70724-2

7. Rimskii-Korsakov, N. A. (2017). Tekhnicheskie sredstva dlia issledovanii dna akvatorii gidrolokatsionnymi metodami. Mezhdunarodnii zhurnal prikladnykh i fundamentalnykh issledovanii, 10 (2), 205-213

8. Shcherbakov, V. (2013). Lazery ishchut miny. Obozrenie armii i flota, 3. Available at: http://otvaga2004.ru/atrina/atrina-ships/ lazery-ishhut-miny

9. Burunina, Zh. Yu. (2003). Proektni zadachi mekhaniky pidvodnykh buksyrovanykh system z pidiomnymy aparatamy. Zbirnyk naukovykh prats UDMTU, 2 (388), 10-19.

10. Blintsov, V., Maidaniuk, P., Sirivchuk, A. (2019). Improvement of technical supply of projects of robotized monitoring of underwater conditions in shallow water areas. EUREKA: Physics and Engineering, 3, 41-49. doi: http://doi.org/10.21303/24614262.2019 .00893

11. Babkin, H. V., Blintsov, V. S., Druzhynin, Ye. A., Kiiko, S. H., Knyrik, N. R., Koshkin, K. V. et. al. (2017). Upravlinnia uspishnymy proektamy stvorennia skladnoi tekhniky. Mykolaiv: Vydavnytstvo Torubary V. V., 336.

12. Nekrasov, V. (2019). Conceptual Designins of Ships. Kyiv-Kherson: Oldi-Plus, 112.

13. Linklater, A. (2005). Design and Simulation of a Towed Underwater Vehicle. Blacksburg, 120. Available at: https://vtechworks.lib.vt.edu/bitstream/handle/10919/33622/AmyThesis. pdf? sequence $=1 \&$ is Allowed $=y$

14. Abdulin, A. J., Senyushkin, N. S., Sukhanov, A. V., Yamaliev, R. R. (2010). Systems of the automated designing as the tool of the decision of the high technology problems. Vestnyk Voronezhskoho hosudarstvennoho tekhnycheskoho unyversyteta, 10. Available at: https://cyberleninka.ru/article/n/ sistemy-avtomatizirovannogo-proektirovaniya-kak-instrumentresheniya-naukoemkih-konstruktorskih-zadach-sudostroeniya

15. Gianpaolo, S., Gianmaria, C., Meneghello, R., D’Angelo, L. (2012). Computer Aided Ship Design: A new Tools Suite for Management, Tracing, Unfolding and Nesting of Shells. Conference: 2 Congresso Nazionale del Coordinamento della Meccanica Italiana. Ancona. Available at: https://www.researchgate.net/publication/232957836

16. Sunde, C. H. (2014). 3D visualization of autonomous underwa ter robots. Available at: https://ntnuopen.ntnu.no/ntnu-xmlui/ handle/11250/238901

17. Chin, C. S. (2017). Computer-Aided Control Systems Design: Practical Applications Using MATLAB ${ }^{\circledR}$ and Simulink ${ }^{\circledR}$. CRC Press, 384. doi: http://doi.org/10.1201/b13697

18. Shahrieel, M., Shahrieel, M. M. A., Li, K., Aripin, K. (2019) Design analysis and modelling of autonomous underwater vehicle (AUV) using CAD. Indian Journal of Geo-Marine Sciences, 48 (7), 1081-1090.

19. Rychenkova, A. Y., Klimenko, E. S., Borodina, L. N. (2020). Geometric modeling and quality assessment of the hull frame surface in COMPASS-3D CAD. Russian Journal of Water Transport, 62, 81-90. doi: http://doi.org/10.37890/jwt.vi62.49

20. Klimenko, E. S., Borodina, L. N., Rychenkova, A. Iu. (2018) Prikladnoe ispolzovanie sistem avtomatizirovannogo proektirovaniia pri modelirovanii mekhanizmov i mashin na morskom transporte. Vestnik VGAVT, 57, 38-44.
21. CAE - Computer-aided engineering. Available at: https://roi4cio com/categories/category/cae-sistema-inzhenernogo-analiza/

22. Minchenko, L. V., Kandratova, T. A. (2017). Sistemy avtomaticheskogo proektirovaniia v sudostroenii. Sovremennye tendentsii tekhnicheskikh nauk. Kazan: Buk, 73-76. Available at: https://moluch.ru/conf/tech/archive/230/12335/

23. Blintsov, V. S., Burunina, Zh. Yu., Lonh, N. T. (2005). Prohramno-tekhnichnyi kompleks dlia morskykh doslidnytskykh vyprobuvan odnolankovykh pidvodnykh buksyrovanykh system. Zbirnyk naukovykh prats NUK, 3, 30-38.

24. Blintsov, A. V., Burunina, Zh. Iu., Klimenko, P. G., Chan, T. D. (2012). Spetsializirovannii modeliruiushchii kompleks dlia issledovaniia effektivnosti sistemy upravleniia podvodnoi buksiruemoi sistemoi. Zbirnik naukovikh prats NUK, 1, 92-97.

25. Wilcox, D. C. (2006). Turbulence Modeling for CFD. D C W Industries, 522

26. Kensek, K. M. (2014). Building Information Modeling. Pocket Architecture: Technical Designes Series. Routledge, 285. doi: http:// doi.org/10.4324/9781315797076

27. Kumar, L. J., Pandey, P. M., Wimpenny, D. I. (Eds.) (2019) $3 D$ Printing and Additive Manufacturing Technologies. Springer, 311. doi: http://doi.org/10.1007/978-981-13-0305-0

28. Vanin, V. V., Perevertun, V. V., Nadkernychna, T. O. (2005) Kompiuterna inzhenerna hrafika v seredovyshchi AutoCAD. Kyiv: Karavela, 336.

29. Hurko, O. H., Yeromenko, I. F. (2011). Analiz ta syntez system avtomatychnoho keruvannia v MATLAB. Kharkiv: KhNADU, 286.

30. Blintsov, O., Sokolov, V., Kucenko, P. (2019). Formulation of design tasks of towed underwater vehicles creation for shallow water and automation of their motion control. EUREKA: Physics and Engineering, 2, 30-42. doi: http://doi.org/10.21303/24614262.2019.00854

31. Stankov, B. N., Pecheniuk, A. V. (2015). Tsifrovye tekhnologii v proektirovanii sudov: ispolzovanie kompleksa FlowVision. SAPR i grafika, 3, 78-82. Available at: http://www.digitalmarine.net/builder/SAPR.pdf

32. Pantov, E. N., Makhin, N. N., Sheremetov, B. B. (1973). Os novy teorii dvizheniia podvodnykh apparatov. Leningrad: Sudostroenie, 216

33. Fossen, T. I. (2011). Handbook of marine craft hydrodynamics and motion control. Norway: John Wiley \& Sons Ltd., 596. doi: http://doi.org/10.1002/9781119994138

34. Blintsov, O. (2017). Devising a method for maintaining manageability at multidimensional automated control of tethered underwater vehicle. Eastern-European Journal of Enterprise Technologies, 1 (9 (85)), 4-16. doi: http://doi.org/10.15587/17294061.2017 .93291

35. Blintsov, V., Blintsov, O., Sokolov, V. (2019). Synthesis of towed underwater vehicle spatial motion automatic control system under uncertainty conditions. Technology Audit and Production Reserves, 1 (2 (45)), 44-51. doi: http://doi.org/10.15587/23128372.2019 .158903

36. Dudykevych, V., Oleksandr, B. (2016). Tasks statement for modern automatic control theory of underwater complexes with flexible tethers. EUREKA: Physics and Engineering, 5, 25-36. doi: http://doi.org/10.21303/2461-4262.2016.00158

37. Larsson, L., Visonneau, F., Stern, M. (2011). CFD in ship hydrodynamics - results of the Gothenburg 2010 workshop. Proc of the IV International Conference on Computational Methods in Marine Engineering, 237-259. doi: http://doi.org/10.1007/ 978-94-007-6143-8 14

38. Blintsov, V., Kucenko, P. (2019). Application of systems approach at early stages of designinng unmanned towed underwater systems for shallow water areas. Eastern-European Journal of Enterprise Technologies, 5 (9 (101)), 15-24. doi: http://doi.org/ $10.15587 / 1729-4061.2019 .179486$

Blintsov Volodymyr, Doctor of Technical Sciences, Professor, ViceRector for Scientific Work, Admiral Makarov National University of Shipbuilding, Mykolaiv, Ukraine, ORCID: http://orcid.org/00000002-3912-2174, e-mail: volodymyr.blintsov@nuos.edu.ua

Kucenko Pavlo, Junior Researcher, Admiral Makarov National University of Shipbuilding, Mykolaiv, Ukraine, ORCID: http://orcid.org/ 0000-0002-7316-0211, e-mail: arcadia.blacksea@gmail.com 